\title{
Correction to: Temporal integration in the perception and discrimination of solid shape
}

J. Farley Norman ${ }^{1} \cdot$ Jessica M. Dukes ${ }^{1} \cdot$ Hannah K. Shapiro ${ }^{1} \cdot$ Karli N. Sanders ${ }^{1} \cdot$ Sarah N. Elder $^{1}$

Published online: 29 April 2020

(C) The Psychonomic Society, Inc. 2020

Correction to: Attention, Perception, \& Psychophysics https://doi.org/10.3758/s13414-020-02031-0

This article was updated to correct an error to Table 2 legend introduced during the production process.

Publisher's note Springer Nature remains neutral with regard to jurisdictional claims in published maps and institutional affiliations.

The online version of the original article can be found at https://doi.org/ 10.3758/s13414-020-02031-0

\section{J. Farley Norman}

Farley.Norman@wku.edu

1 Department of Psychological Sciences, Ogden College of Science and Engineering, Western Kentucky University, Bowling Green, KY 42101-2030, USA 